\title{
GUIDELINES FOR MIXING AND PLACING THERMALLY CONDUCTIVE CEMENTITIOUS GROUT (Mix 111)
}

\author{
M.L. Allan \\ Department of Applied Science \\ Brookhaven National Laboratory \\ Upton, New York
}

\subsection{Materials}

\subsection{Cement}

The cement used shall conform to ASTM C 150-Type I. If the site conditions require that sulfate resistant cement is necessary then Type II or Type $\mathrm{V}$ cement can be used. Cement that already contains a waterproofing additive should not be used as this has been found to cause slight foaming of the grout and reduce the thermal conductivity.

Cement should be kept dry at all times, stored on pallets and covered with a tarpaulin or plastic sheet. Any bags of cement that are damaged (e.g., torn) or that have been exposed to water should be discarded. The cement should be fresh and free from any hard lumps.

\subsection{Bentonite}

The decision to use to bentonite will depend on the mixing equipment used. For low shear (e.g., paddle) mixers it is recommended that a small amount of bentonite is used to aid grout stability and reduce segregation of sand. The bentonite used shall be 200 -mesh unadulterated sodium montmorillonite. The viscosity of the grout will increase with increasing proportion of bentonite.

\subsection{Water}

The mixing water shall be potable. Water with excessive impurities may affect the final properties of the grout.

\subsection{Silica Sand}

The silica sand shall conform to ASTM C 33 in terms of soundness and absence of deleterious substances only. The particle size gradation shall conform to that in Table 1 below. The sand used in this work was purchased from New Jersey Pulverizing Co. (Test Card 3343-97). However, other sand suppliers should be able to blend sand to meet the specified gradation.

The bags of sand should be kept dry at all times and stored on a pallet. Sand that has become wet should not be used as this will increase the water/cement ratio of the grout. 
Table 1. Specification for Particle Size Gradation of Silica Sand

\begin{tabular}{|l|c|}
\hline Sieve No. $($ Size,$\mu \mathrm{m})$ & Percentage Passing $(\%)$ \\
\hline $8(2360)$ & 100 \\
\hline $16(1180)$ & $95-100$ \\
\hline $30(595)$ & $55-80$ \\
\hline $50(297)$ & $30-55$ \\
\hline $100(149)$ & $10-30$ \\
\hline $200(75)$ & $0-10$ \\
\hline
\end{tabular}

\subsection{Superplasticizer}

The superplasticizer shall be $\sim 42 \%$ sodium naphthalene sulfonate conforming to ASTM C 494 Type F. The product used in this work was Rheobuild 1000 from Master Builders Technologies. Other manufacturers supply equivalent products. Superplasticizer can often be obtained from local concrete ready mixed companies.

\subsection{Equipment}

The grout can be mixed in either a low shear (paddle) or high shear (colloidal) grout mixer. Mix 111 in the proportions given below has been designed for compatibility with a paddle mixer. Improved sand carrying capacity, decreased water requirement, reduced bleeding and greater flowability of grouts is usually achieved with grouts mixed in colloidal mixers.

It is preferable to use a grout mixer in conjunction with a larger capacity agitator in which the grout is stored and agitated until use. This is necessary to keep the particles in suspension, and, in the case of thixotropic grouts, keep the grout mobile and fluid. As discussed previously, the grout can be pumped continuously from the agitator tank while the next batch is mixed. Thus, pumping is not interrupted and the risk of plugging the tremie tube is reduced. It is critical that a proper grout mixer suited to cement-sand grouts be used. Mixing of the grout by hand, pumps or concrete ready mix trucks is not acceptable.

Piston pumps are recommended for pumping the cement-sand grouts. Excessive wear may be encountered when using a helical rotor (progressing cavity/Moyno) pump. Based on the field trials a minimum 1.25-inch diameter tremie tube with an open end and several side discharge outlets is recommended. 


\subsection{Grout Mix Proportions}

The basic mix is given in Table 2. The amount of grout that can be mixed at once will depend on the capacity of the grout mixer. It is preferable to mix as much as possible per batch.

Depending on the mixing equipment and actual particle size gradation of sand used, the rheology of the grout may vary. Irrespective of the mixer used, it is recommended that trial mixes are performed and water, bentonite and/or superplasticizer adjusted so that suitable pumpability is achieved. However, use of excessive water will be detrimental to the hardened grout properties (e.g., shrinkage, permeability, durability, thermal conductivity) and probably induce segregation of the sand. Superplasticizer should be limited to a maximum of $20 \mathrm{ml} / \mathrm{kg}$ cement. This is equivalent to $851 \mathrm{ml}$ (29 fluid ounces) per $94 \mathrm{lb}$. bag of cement.

Since the grout properties are very sensitive to water/cement ratio and superplasticizer dosage, it is critical that the amounts of water and superplasticizer required for a grout batch are measured accurately. This can be achieved through use of graduated containers or, in the case of water, with a water meter.

Table 2. Mix Proportions and Yield for Batch of Mix 111 Based on One Bag of Cement.

\begin{tabular}{|l|l|}
\hline Cement & $1 \times 94 \mathrm{lb}$. bag \\
\hline Water & 23.5 litres (6.19 U.S. gallons) \\
\hline Sand (conforming to spec.) & $2 \times 100 \mathrm{lb}$. bags \\
\hline Superplasticizer & $\begin{array}{l}639 \mathrm{ml} \mathrm{(21} \mathrm{fl.} \mathrm{oz)} \mathrm{(approximately,} \mathrm{not} \mathrm{to} \\
\text { exceed } 851 \mathrm{ml})\end{array}$ \\
\hline Bentonite (optional) & $470 \mathrm{~g}(1.04 \mathrm{lb})$ \\
\hline Yield & 72.2 litres (19.1 U.S. gallons) \\
\hline
\end{tabular}

\subsection{Recommended Grout Mixing Procedure}

The recommended procedure for mixing the cement-sand grout in a paddle mixer is as follows:

1. Pre-mix bentonite with the required, measured quantity of water until bentonite is uniformly dispersed. (A Jiffy mixer may suffice).

2. Place water-bentonite mix in grout mixer.

3. Place required measured quantity of liquid superplasticizer in mixer.

4. Start mixer at low speed.

5. Mix water-bentonite and superplasticizer for approximately 10 seconds. Care should be to avoid air entrainment by mixing at excessively high speed. 
6. Gradually add required quantity of cement in mixer and increase mixer speed. Mix for approximately one to two minutes or until cement is well dispersed.

7. Gradually add required quantity of sand in mixer and increase mixer speed if necessary.

8. Mix grout for specified time (Maximum of 5 minutes should be adequate).

9. Transfer grout to agitator. If agitator is not used then transfer grout to hopper. Grout in hopper should be agitated occasionally with Jiffy mixer or similar.

\subsection{Quality Control}

Every batch of freshly mixed grout should be measured for specific gravity prior to pumping. This requires use of a mud balance available from companies such as Baroid and the test procedure is given in ASTM D 854-83. The specific gravity is sensitive to water/cement ratio, sand/cement ratio and uniformity of mixing. Mix 111 with the proportions given above has a specific gravity of 2.18 (Density $=18.2 \mathrm{lb}$./gal). As a guide, the specific gravity should be $2.18 \pm 0.02$. Measuring flow time in accordance with ASTM C 939 can also be performed to check for grout pumpability and uniformity. All data and any changes in grout mix proportions or mixing procedure should be documented by the grouting contractor.

Samples should also be taken for future laboratory thermal conductivity testing. In this case, the grout should be poured into a suitable leakproof mould, the dimensions of which depend on the equipment that will be used to measure thermal conductivity. The grout samples should be sealed or covered with plastic for 24 hours and maintained at temperature as close as possible to $20-25^{\circ} \mathrm{C}$. After 24 hours the samples should be demoulded and immersed in a water bath at $20-25^{\circ} \mathrm{C}$ to cure for at least 7 days prior to testing.

\section{ACKNOWLEDGEMENT}

This work was supported by the U. S. Department of Energy Office of Geothermal Technologies and performed under contract number DE-AC02-98CH10886.

\section{FURTHER INFORMATION}

M.L. Allan, Thermal Conductivity of Cementitious Grouts for Geothermal Heat Pumps, FY 97 Progress Report, BNL 65129, November, 1997.

M.L. Allan and A.J. Philippacopoulos, Thermally Conductive Cementitious Grouts for Geothermal Heat Pumps: FY 98 Progress Report, BNL 66103, November 1998.

M.L. Allan and A.J. Philippacopoulos, Properties and Performance of Thermally Conductive Cement-Based Grouts for Geothermal Heat Pumps: FY 99 Final Report, BNL no. pending, November 1999. 


\section{DISCLAIMER}

This document was prepared as an account of work. sponsored by an agency of the United States Government. It describes guidelines for mixing a superplasticized cementsand grout formulation developed for geothermal heat pump applications. Pertinent state regulations must be followed when grouting boreholes used with geothermal heat pumps and this document does not replace such regulations. Neither the United States Government nor any agency thereof, nor any of their employees, nor any of their contractors, sub-contractors, or their employees makes any warranty, express or implied, or assumes any legal liability or responsibility of the accuracy, completeness, or usefulness of any information, apparatus, product or process disclosed, or represents that its use would not infringe privately owned rights. Reference herein to any specific commercial product, process, or service by trade name, trademark, manufacturer, or otherwise, does not necessarily constitute or imply its endorsement, recommendation, or favoring by the United States Government or any agency thereof. The views and opinions of authors expressed herein do not necessarily state or reflect the United States Government or any agency, contractor, or subcontractor thereof. 